\title{
A reproduction of the ancient Bandjeli's steel-making process
}

\author{
Pali Kpelou ${ }^{1,}$, , Gnande Djeteli ${ }^{1}$, Ayi Djifa Hounsi ${ }^{1}$, Hans Peter Hahn ${ }^{2}$, \\ Tiburce Ahouangbe Aboki ${ }^{3,4}$, Kossi Napo ${ }^{1}$ \\ ${ }^{1}$ Departement of Physics, Université de Lomé, Lomé, Togo \\ ${ }^{2}$ Institut für Ethnologie / Campus Westend, Universität Frankfurt, Grüneburgplatz 60323 Frankfurt am Main, Germany \\ ${ }^{3}$ GMS-LPCS UMR7045 / Chimie Paristech Paris Cedex 05, France \\ ${ }^{4}$ Palais de la découverte / Universcience, Avenue Franklin Roosevelt, 75008 Paris, France
}

\section{Email address:}

palikpelou@gmail.com (P. Kpelou),pkpelou@yahoo.fr (P. Kpelou),gdjeteli@yahoo.fr (G. Djeteli), romeo7fr@gmail.com (A. D. Hounsi) Hans.Hahn@em.uni-frankfurt.de (H. P. Hahn)

\section{To cite this article:}

Pali Kpelou, Gnande Djeteli, Ayi Djifa Hounsi, Hans Peter Hahn, Tiburce Ahouangbe Aboki, Kossi Napo. A Reproduction of the Ancient Bandjeli’s Steel-Making Process. International Journal of Materials Science and Applications. Vol. 3, No. 5, 2014, pp. $217-225$.

doi: $10.11648 /$ j.ijmsa.20140305.23

\begin{abstract}
This paper presents an ancient traditional steel-making process of Bandjeli, in the Bassar Region in the Republic of Togo (West Africa). The iron specialists of Bandjeli have owned technical knowledge to cast direct reduced iron (DRI) likely direct reduced steel (DRS). This know-how was transferred to each generation over many centuries. The description of this steel-making process is focused on the steps that lead to the iron ingot: the construction of the furnace, the raw materials collection and their preparation, the furnace filling and the smelting operation. Microstructures of as-smelted and thermo-mechanical treated samples as well as hardness data are presented. Optical and SEM micrographs indicate a Widmannstätten structure type, comprising of a plates or needles of ferrite or alpha iron (Fe $\alpha)$ in light contrast and grains of pearlite (dark contrast). Micro-hardness measurements indicate values ranging from 100 to $700 \mathrm{Hv}$, this field covers the micro-hardness values of the ferrite and pearlite. Microstructural and mechanical properties of the as-obtained product suggest direct steel processing from Bandjeli's natural draught furnace. These results are necessary for further investigations on the as-smelted steel and on the contribution of this traditional smelting technology to the iron industry.
\end{abstract}

Keywords: Traditional Steel-Making Process, Natural Draught Furnace, Direct Reduced Steel, Microstructure, Hardness

\section{Introduction}

Iron is the material of the industrial revolution of 18-19 century in Europe that marks a major turning point in history, where changes in agriculture, manufacturing, mining, transportation, and technology have deep effects on the social, economic and cultural living conditions of people. Mostly, it was due to the increasing quantity of the iron produced by the blast furnace. This latter was just the evolution of an ancient production system of iron, by traditional furnaces [1-3]. During the past centuries, such activities around iron were found in various traditional societies from Asia [3] to Africa [4] through Europe, due to iron ore availability on Earth. This probably explained why iron is still the most metallic material used today in various devices and plants. In Europe, the transition to modern technics was successful because of the commercial demands of iron, but in Africa, colonization hindered its development [4].

Most of the interests around traditional iron metallurgy in Africa are cultural with various scopes [5-8]. Some of them have to find the origin of the art of the iron smelting process in Africa [9;10]. Others were focused on the technical knowledge of the smelting and the ways it shapes the social behaviors of smelters, blacksmiths, farmers, traders, and their environment within the village and it surrounds $[11,12]$. The transmission's modes from generation to generation and the spiritual, rituals and symbolism around the iron smelting were also the subjects of several studies [12,13]. Research in the Bassar region in the Republic of Togo follows the above-described goals, particularly about the smelting technology of Bandjeli. Studies on this community were 
conducted by historians [4], and archaeologists [11, 14-16], anthropologists [1, 12, 17-19], geologists [20-22] and missionaries [23-25]. In the Bassar area, the smelters are also farmers during the raining season, peculiarity, which was observed also in the Dogon region in Republic of Mali $[26,27]$. This is in contrast with others parts in the world where the smelters are only specialized in activities around the iron.

Furthermore, the Bandjeli smelters have kept their knowledge through the time so they can reproduce the whole process on-demand $[1,5]$. Hahn $[1,2]$ had conducted a reproduction of the smelting process of Bandjeli in late 1988 where we assisted and recorded information about all the steps of the smelting process. The objective was not only anthropological focusing on smelting skills of people of Bandjeli but also metallurgical. Microstructure observations and hardness data obtained by Hahn in 1988 suggested that metallurgist of Bandjeli produced directly an iron or a kind of steel. Van der Merwe [28] also conducted extensive research on Africa's smelting process and observed that the as-smelted product is a blend of various carbon content up to about 2.2 wt.\% steel, which was forged with mechanical properties suitable for agricultural tools. Furthermore, no improvement of the ancient technology for industrial applications towards economic development was undertaken [6]. This paper aims to describe a reproduction of the smelting process of Bandjeli and to present metallurgical study including the characterization of the final iron product. Special emphasis will be given to identifying in the microstructures what may be characteristic of the as-obtained product. The goal is to make a comparative and complementary study to those conducted by Hahn.

\section{Historical Aspects}

Bandjeli is a village located in Northern Togo at about 360 $\mathrm{km}$ from the Guinea cost (Fig.1a) within the savannah corridor of West Africa (Fig. 1b) [29]. The history of the iron industry of Bassar, which includes the smelting activities of Bandjeli, is described in depth in the $\mathrm{PhD}$ dissertation of Goucher [6]. She stressed the Togo's past and the interests of Germans discovering a large-scale smelting and the smithing works when they arrived in the Bassar region in 1894. Using the amounts of slags in the smelting areas along with archaeological excavations, de Barros [15] dated the beginning of the ironworking at about the fourteenth century AD. From these studies the history of Bassar iron industry can be divided into four periods, which reflect major changes in the level of iron production. The first period from late-first millennium $\mathrm{AD}$ to $1350 \mathrm{AD}$ is characterized by a small-scale production for basically local needs. The second period, 1350-1600 AD is characterized by a significant regional iron production. During the third period, 1600-1800 $\mathrm{AD}$, there was a large-scale production for supra regional export. During the previous two periods productions exceeded local needs and was exported to other areas and populations such as: Mamproussi and Dagomba in the North of the Republic of Ghana, Tchokossi, Lamba and Kabye in the North of Togo. The last period, 1800-1950 is characterized by an expanding production, disruption and eventual decline $[5,30]$ caused by the charcoal supplies shortages [15].
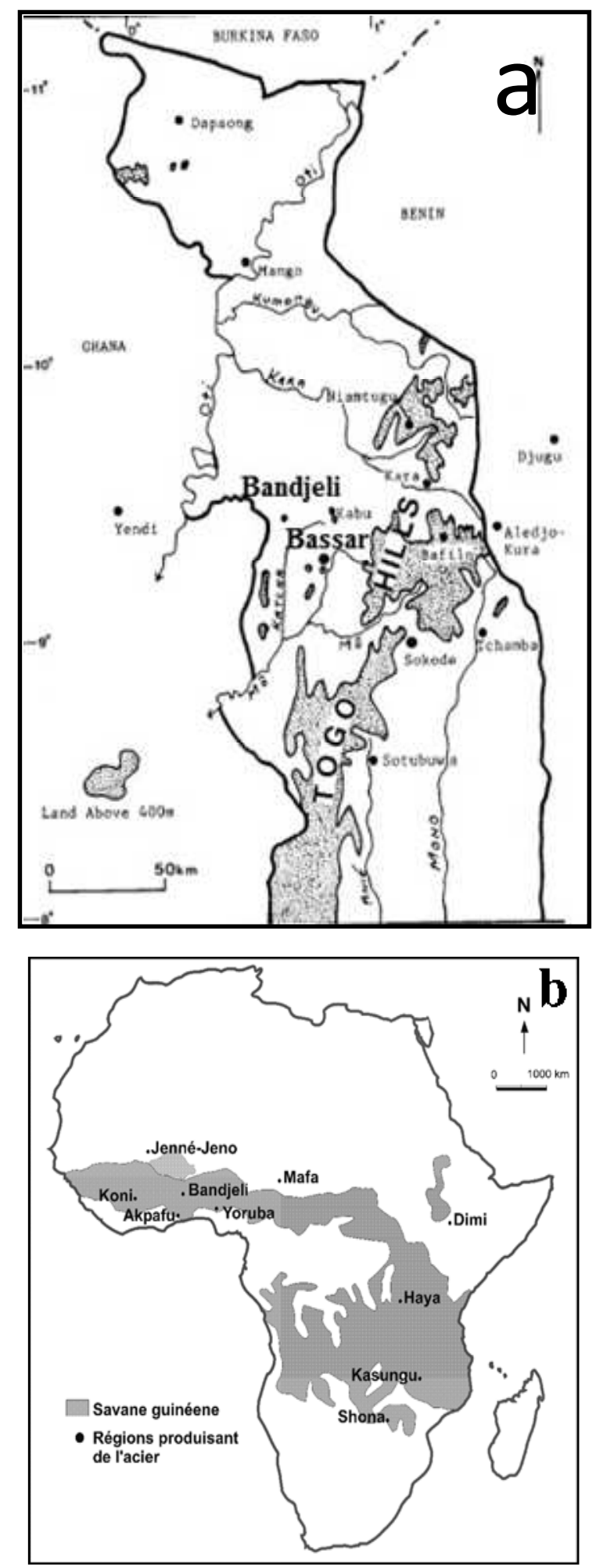

Figure 1. Locations of the village of Bandjeli on the geographic maps of the republic of Togo (a) and Africa (b). 
According to previous results, the iron industry of Bandjeli is to be compared to that of the great African centres of iron development like Mema [31] and Meroe [32] respectively in the actual Republic of Mali and Republic of Sudan. The Bandjeli's iron industry, with its total production of 14000 to 32000 tons left at least $82000 \mathrm{~m}^{3}$ of slag [1]: this corresponds to an annual production of 150 to 200 tons of iron for sale $[5,14]$. This production may be the highest in sub-Saharan Africa's history. There were over 500 natural draught furnaces built around houses observed by colonial travellers (Fig. 2a) [33]. The furnaces produce horseshoe shaped ingots $[1,23]$, that can reach a weight at about $27 \mathrm{~kg}$ (Fig. 2b) [33].
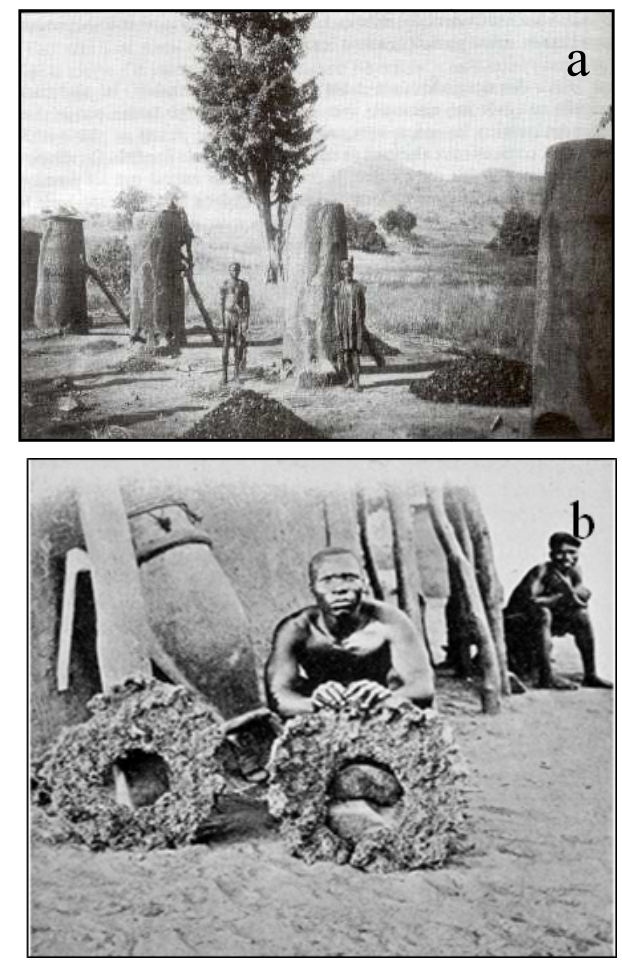

Figure 2. Historical gallery of a field of furnaces reported in ref. 33 (a) and the typical morphology (b) of the as-smelted ingot (ref. 23).

\section{Smelting Process: The Bandjeli Natural Draught Furnace}

The smelting process can be divided into four tasks: the construction of the furnace, the furnace inputs (iron ore, charcoal and others ingredients collection and preparation), the furnace filling and ignition, and the smelting operation.

\subsection{Construction of Bandjeli Furnace}

Setting up a smelting furnace required the previous agreement by the traditional chief or the regent. A master smelter (MS) with the help of his team directs the natural draught furnace's construction and the smelting operations. He took the major technical decisions, sometimes after discussions with the regent, during the whole process. Fig. 3 and Fig. 4 are illustrations of the materials described in this section.

\subsubsection{Construction of the Furnace Walls}

The construction of the reproduced furnace occurred in November 1988 during 12 days from 10 to 22 November. This period correspond to the dry season, the 'harmattan' season where a dry and hot air blows over the landscape. A place not far from the houses was chosen, with a lateritic soil thoroughly cleaned for the implementation of the furnace. Fig. 3a-c illustrate the furnace construction steps and Fig. $3 \mathrm{~d}-\mathrm{f}$ indicate the reduction process evolution. A picket was fixed on the ground and, by means of a piece of cord, a circle of about $100 \mathrm{~cm}$ diameter was drawn (Fig. 3a). A circular foundation hole of about $3 \mathrm{~cm}$ deep is practiced following the previous circle that received some small available fragments from old furnaces. Lumps of clay were shaped and reshaped to construct a wall of about $10 \mathrm{~cm}$ thick (Fig. $3 b)$. The outer wall of the furnace is then dusted with a fine powder of clay in order to absorb moisture and to avoid the rapid drying of the wall. The wall is tilted inward in order to have the usual conical shape of a shaft furnace. The initial designated locations of the furnace's door and tuyeres holes were pictured on the wet wall with fingers. The door was located Nord-West to protect it from rain and wind. Its dimensions were set up by a piece of wood with a height two times that of the width. The locations of the tuyeres can be observed in the bottom of the furnace in Fig. 3c. However, the door was not opened avoiding the risk of collapse or cracking of the wall. Then, using a machete, the vent hole diametrically opposite to the door was carefully opened at the $4^{\text {th }}$ day of the construction. From the opened hole, opposite to the door called the 'master vent', air flows inside the furnace and the drying process of the furnace's wall is increased. The other holes were disengaged from the outside without opening them completely, because the wall is still very wet. On the $5^{\text {th }}$ day, the door and the other ventilation holes were completely opened and the furnace was then left for natural drying for about 5 days before plastering.
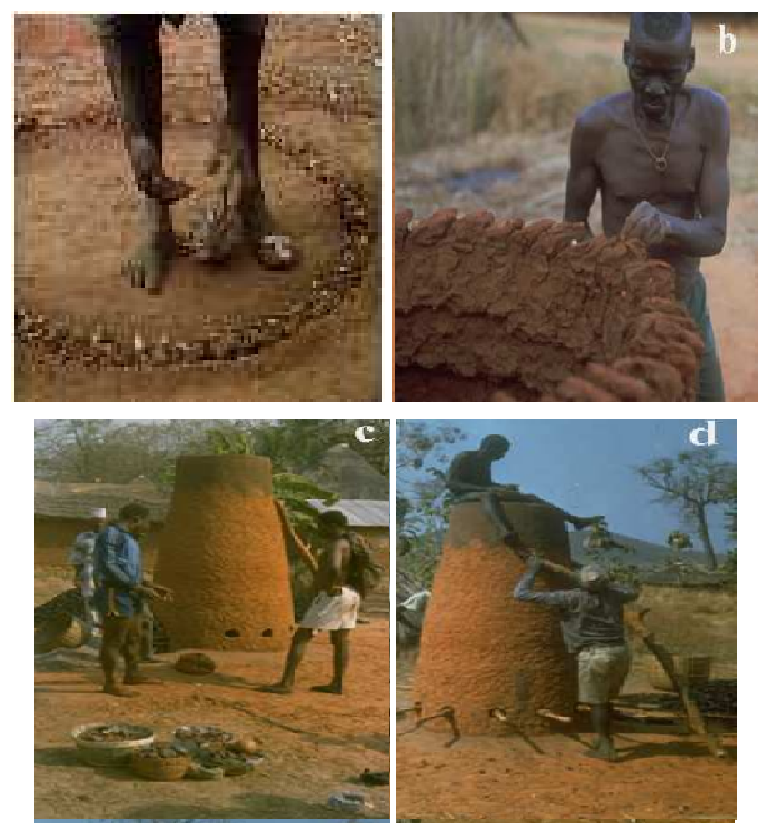


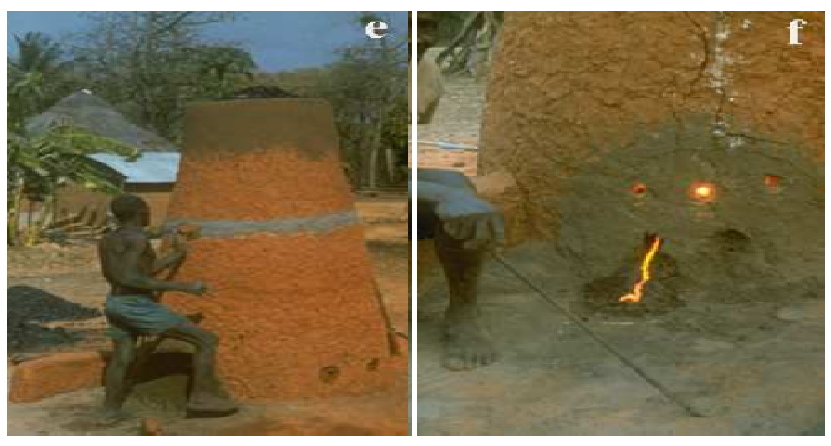

Figure 3. The Bandjeli furnace construction steps: (a) ground delimitation, (b) walls elevation at half height construction with the conical shape, (c) finished furnace with the tuyeres location holes and the gathered inputs charges around, (d) charges filling into the furnace and the set up of the tuyeres in the bottom, (e) external lining indication of the level of the ore within the furnace, 'the belly', (f) liquid slag flow 28 hours after the ignition of the furnace.

\subsubsection{Dimensions of the Bandjeli's furnace}

Bandjeli's draught furnace constructed in November 1988 is about $2.13 \mathrm{~m}$ high (Fig. 4a) and the wall thickness is about $12-18 \mathrm{~cm}$. The furnace walls are built from composite of clay and straw from harvested 'fonio' (Digitaria exilis). This furnace can be taller from the bottom to top of about 2-4 m. The inner diameter of the bottom is about $1-1.5 \mathrm{~m}$, the top diameter $0.7-1 \mathrm{~m}$. The door has a width of $70 \mathrm{~cm}$ and a height of $30 \mathrm{~cm}$. The inner diameter of tuyeres is about $3 \mathrm{~cm}$ and there are 10 or 12 tuyeres around the furnace (Fig. 4b).

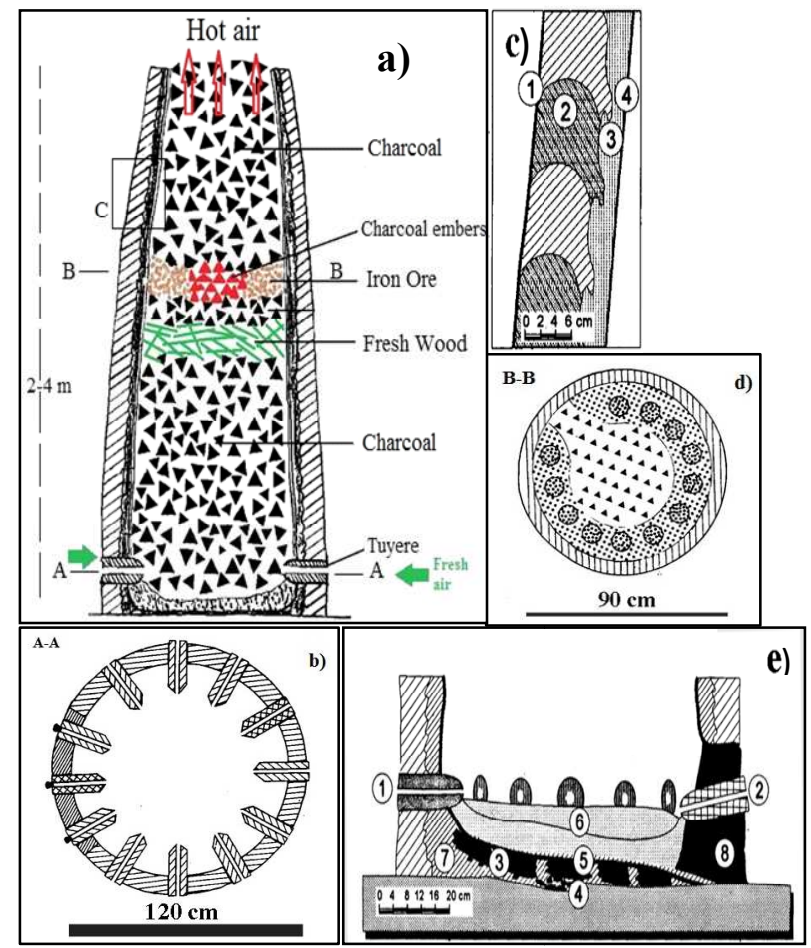

Figure 4. Scheme of the draught furnace showing its characteristic shape, dimensions and input charges levels (a); cross-section A-A showing the arrangement of the tuyeres at the bottom of the furnace (b); details of the furnace wall constitution (c); cross-section B-B showing the iron ore arrangement (d); lateral section of the hearth of the furnace with the various functional characteristics (e) (see text).

\subsubsection{Plastering}

The internal wall surface is one of the most important parameters to ensure the success of the smelting operation. The plastering operation is intended to fashion the quality of the surface shown in Fig. 4c that must withstand high temperatures and have no chemical reaction with iron ore. For this purpose, a kneaded wet clay powder was mixed with a gel preparation and applied on the wall upon the thickness at about $1-3 \mathrm{~cm}((3)$ in Fig. $4 \mathrm{c})$. The gel preparation is a solution of gel and an amount of black-reddish sand collected in the nearby river. The gel is the product of beaten bark of particular tree immerged in water. The plaster then obtained, was carefully and manually polished to remove any irregularities on the wall that may impede the descent of the load during the smelting. To finish the furnace inner wall surface, the black-reddish sand ((4) in Fig. 4c) was mixed with water and kneaded then applied to all areas plastered. The surface was then beaten with wooden bats. This action makes the surface very smooth and uniform. The external plaster (1) and the lump of clay (2) are also represented in Fig. 4c. The vents walls are plastered, coated with the black sand and beaten. The bottom of the furnace is cleaned of all debris from either the construction or plastering. Then the MS digs a depth of $10 \mathrm{~cm}$ below the ground level. The foundation thus formed is inclined towards the door. All layers that will be added keep this slope. It will later allow last to flow freely to the door. These finishing operations lag two days and complete the construction of the furnace. The furnace is then left for 21 days, a time to prepare charcoal and let it dry and most importantly, a time to smelting team members to harvest their crops of mil.

Two hours before the loading and the ignition of the furnace, a parkia biglobosa barks were introduced into the furnace to a thickness of 40 to $50 \mathrm{~cm}$ and inflamed, presumably to dry again the furnace or to preheat it. The small amount of ash obtained from this combustion was preserved, and later on used to paint the level of the belly on the furnace (Fig. 3e).

\subsubsection{Tuyeres}

The tuyeres were made the furnace ignition's day, using wood rods of about $3 \mathrm{~cm}$ in diameter and longer than $30 \mathrm{~cm}$. The stems are wet and covered with kneaded clay (the same as that used for internal plastering) to a thickness of $3 \mathrm{~cm}$. The stems thus covered are then introduced into the vents as can be observed in Fig. 3d. The stems will be removed as soon as the furnace will be charged thereby releasing the tuyeres holes (Fig. 3e). All tuyeres are disposed horizontally except that which is in the middle of the door. It is installed with an angle of $25^{\circ}$ inclination to the horizon and allows observation of the slag formation during the reduction process (Fig. 4a \& e). In addition, 9 of the 12 tuyeres are set in equal distance while the 3 others were set in reduced equal distance within the furnace's door width (Fig. 4b).

\subsubsection{The Hearth}

This part of the furnace that will receive the smelted products is complex (Fig. 4e). It was constituted by 
alternated layers of pieces of old furnace walls (5) covered by the black-reddish sand (7), slags (4), a white sand - a pure quartz (6), a black sand wall (8) forming the door of the furnace. The white sand is filled up to the height just under the nozzle of the tuyeres. Note that the sands were carefully sifted before pouring into the furnace.

\subsection{The Bandjeli's Furnace Operating Conditions}

\subsubsection{The Inputs Materials}

Bandjeli steel is produced from an iron ore which in weight percentage (wt.\%) contains of about: $(9-20) \% \mathrm{SiO}_{2}, 75 \%$ $\mathrm{Fe}_{2} \mathrm{O}_{3}$, an equivalent of about 55 to 65 wt. $\%$ of pure iron.

It was collected and ground at about $1 \mathrm{~cm}$ of diameter the very same day of the furnace ignition. The charcoal was elaborated from the calcination of Prosopis Africana tree or other trees with similar hard wood. The mentioned species gives a hard charcoal with good caloric properties. It was prepared during the two previous days before the furnace's ignition. An amount of about $108 \mathrm{~kg}$ of charcoal, most from Prosopis Africana, was loaded into the constructed furnace. It is worth to note that not the whole charcoal, the furnace can be filled with a mixed hard and soft woods charcoals but with the latter in small proportion.

The fresh wood was also cut the furnace ignition's day and the load was about the same volume like the ore. It consisted of stems at about $20-30 \mathrm{~cm}$ length and $3-6 \mathrm{~cm}$ in diameter.

The other materials entering the furnace were the white and the black sands. The white sand is pure quartz, which served as fudge in the hearth while the black sand is composed with quartz and organic matters. The sand was carefully sifted before the introduction in the furnace.

\subsubsection{The Furnace Loading and Ignition}

The furnace was loaded by alternating layers (Fig. 3d and 4a). The MS sat across the top of the furnace, receives materials from his team members and fills the furnace. The first layer consists of about $54 \mathrm{~kg}$ of charcoal, which he puts on the sand bed. Then he loads the furnace with fresh woods over the first charcoal layer. Another charcoal layer of about $9 \mathrm{~kg}$ is added which receives the crushed iron ore of about 35 $\mathrm{kg}$. The ore is disposed and spread along the wall in 12 mounts, so that the areas above the door and the centre of the furnace are not covered as can be seen in the cross-section B-B in Fig. 4d, giving the horse-shoe shape. The space in the middle ensures continuity with the final charcoal layer. This latter at about $45 \mathrm{~kg}$ fills the remaining volume of the furnace after the ignition by the deposition within the hollow of iron ore of charcoal embers and barks of Parkia biglobosa tree. This means the ignition takes places simultaneously with the filling. Thus, fire and heat spread from the middle level of the furnace.

In total, the furnace is filled with $108 \mathrm{~kg}$ of charcoal and $35 \mathrm{~kg}$ of crushed ore corresponding to a proportion iron ore/charcoal of about $1 / 3$ in weight. This proportion is about $1 / 10$ in volume. The loading and ignition operation was done 25 days after the complete construction of the furnace.

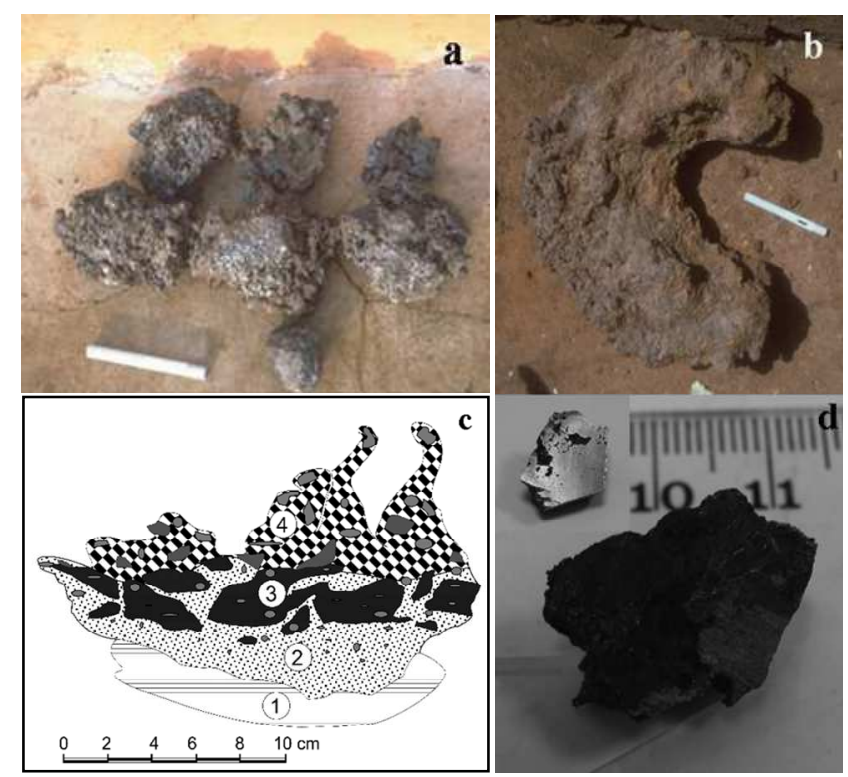

Figure 5. The as-smelted lump: (a) pieces of the broken as-smelted lump, (b) typical horseshoe morphology and size of the as-smelted lump, (c) Scheme of the lateral section of the as-smelted lump with indication of various chemical phases, (d) Aspect of the inner part of the as-smelted lump.

The stems are then removed from the tuyeres, fresh air enters through the tuyeres and hot air escapes through the top of chimney of the furnace. This ensures a natural ventilation and convection in the furnace, the origin of the classification as a "natural draught furnace" or induced draught furnace. The MS then paints a line with the preserved hydrated ash on the furnace at a level at about 1.3 $\mathrm{m}$. This area is named belly" and it roughly locates the position of the iron ore load in the furnace, position designed as the belly of the furnace.

\subsubsection{The Smelting Process}

The process essentially relied on practical skills of the MS who did not use any modern scientific instruments for the evaluation of the different amounts of physical and chemical parameters involved in the smelting operation. The furnace was lighted in the afternoon at $4 \mathrm{pm}$. Before sunset, at $6 \mathrm{pm}$, the (MS) made a final control: a twig glowing and smoking was seen at the end of the tuyeres. He concluded that the process is progressing normally by noting that the smoke that emerges is absorbed. At about 10 hours after the ignition, the temperature in the hearth measured by the introduction of a thermocouple into one of the tuyeres was constant at about $800^{\circ} \mathrm{C}$. The next day in the morning around $7 \mathrm{pm}$ the MS returned with an iron rod that he introduced through the tuyeres checking for occurrence of slag. Then he observed through tuyeres the light colour. If the light is dim in some areas and clear in others, then up to two or three buffers are introduced for some minutes up to half an hour in the tuyeres of the areas where it is clear. This allows the MS to control and homogenize the temperature and the reduction process in the furnace. From 10 am onwards the MS returned to the furnace every hour. With the rod, he controls and cleans the tuyeres from slags, which might eventually block the airflow. 
At 1 p.m., 21 hours after the ignition, the hot phase begins. The MS marks this period by an acoustic signal. He perceives a louder crackling through the tuyeres. The hot phase is the period during which the temperature is the highest in the furnace. And thus corresponds to the period of ore reduction. From this time, the MS does not any more leave the furnace. He regularly observes through the central tuyeres of the door to determine the amount of slag formed. When he considers there is enough slag, he practises a small hole into the door, and the liquid slag flows out through a small canal dug for this purpose beneath the furnace and solidified quickly. Another quick introduction of the thermocouple into the tuyere indicated a temperature well above $1000^{\circ} \mathrm{C}$. The thermocouple which is limited to $1200^{\circ} \mathrm{C}$ burnt from this measurement. The slag usually appears 24 hours after the ignition. The liquid slag appearance proves that the hot phase is near. The hot period lasts not more than 6 hours. After this phase, no control is necessary any more. In the late afternoon of the third day, between 4 and 5 p.m., the door is opened and the lump is extracted. In the case of this smelting, the as-smelted product was broken (Fig.5a) because of the difficulties to remove it from the door. It sticked to the ends of the tuyeres and it was difficult to extract it. Usually, a horseshoe shaped lump is extracted as we have found at a smith (Fig. 5b) at about $70 \mathrm{~km}$ from Bandjeli. The as-smelted lump weight was evaluated to $8-12 \mathrm{~kg}$ which can be rated to one third the amount of the starting iron ore of about $35 \mathrm{~kg}$ or one half the proportion of the iron in the ore evaluated at about $24 \mathrm{~kg}$. According to the MS, the smelting was successful and can be considered as among the best obtained so far. This technical appreciation is in agreement with historical observations [23]. A scheme in Fig. 5c shows the different parts of the as-smelted material; remaining sands mixed with the slag (1), which consists of a pure fayalite (2), some grains of iron of about 10-100 mm (3), and a blend slag and pure iron (4). This latter is not for use according to the MS. The as-smelted material was divided into 10 parts of about 2 $\mathrm{kg}$ and shared. Samples for examinations were cut from a part shown in Fig. 5d.

\section{Description of Samples and Experiments}

The sample used in this work is cut from an ingot provided by the actual district chief of Bandjeli $\mathrm{Mr}$. SERTCHI Madjintiba. The authors of this work heard from Mr. Madjintiba that the raw material was smelted through the application of the traditional Bandjeli's process described above. Small specimens were cut out from this provided sample and mounted and treated following a standard metallographic procedure before being examined under the optical microscope, the scanning electron microscope (SEM). The specimens were etched around 5 second using the solution of $3 \%$ volumetric nitric acid in balance methanol. XRD diagrams were obtained using a
D5000 Bragg-Brentano type apparatus from Siemens in reflection mode. The wavelength of copper $\left(\mathrm{k}_{\alpha}=1.5406 \AA\right)$ was used in a step scan mode range $20^{\circ} \leq 2 \theta \leq 120^{\circ}$, with a step of $0.04^{\circ} 2 \theta$ and a step time of $2 \mathrm{~s}$. Micro hardness is measured using MHT-200 Series Micro Vickers Hardness Tester with a load charge of $300 \mathrm{~g}$ during $5 \mathrm{~s}$.

\section{Results}

Fig. 6 is a collection of optical micrographs obtained from examinations of polished samples taken from the as-smelted steel. Fig. 6a and c are obtained from the sample of 1988 smelting; Fig. $6 \mathrm{~b}$ and d are micrographs obtained from more recent smelting ingot. Fig. $6 \mathrm{a}$ and $\mathrm{b}$ are quite similar. The microstructure is the well-known Widmannstätten structure, comprising of a plates or needles of ferrite or alpha iron $(\mathrm{Fe} \alpha)$ in light contrast and grains of pearlite (dark contrast). The pearlite is a bi-phased structure of smaller Fe $\alpha$ needles and short rods of cementite compound $\left(\mathrm{Fe}_{3} \mathrm{C}\right)$. The $\mathrm{Fe} \alpha$ needle thickness is about $10-60 \mu \mathrm{m}$ in the grain boundary while its size in the pearlite is about $3 \mu \mathrm{m}$. Additional small plates arise on the large ferrite grain boundaries and can be identified as a ferrite; this phenomenon is probably due to a divergence between two ferrites plates. Fig. 6c shows again a Widmannstätten structure after a traditional smithing). However, it must be checked whether the phase within the ferrite needles is still a pearlite. A recent sample annealed at $800^{\circ} \mathrm{C}$ during 1 hour in laboratory (Fig. 6d) indicates microstructure rather similar to a bainite (see inset Fig. 6d). This suggestion is being in investigation. In addition, the small plates occurring in the large needle of ferrite as grains boundaries has been removed after a thermal treatment.

It is worth to note that the as-smelted material contains pores, resulting from the gas bubbles entrapped during solidification, seen as dark areas on the micrographs. In general, the microstructure is not homogeneous like in Fig. $6 \mathrm{c}$ picturing the natural reduction process close to the thermodynamic conditions (slow cooling).

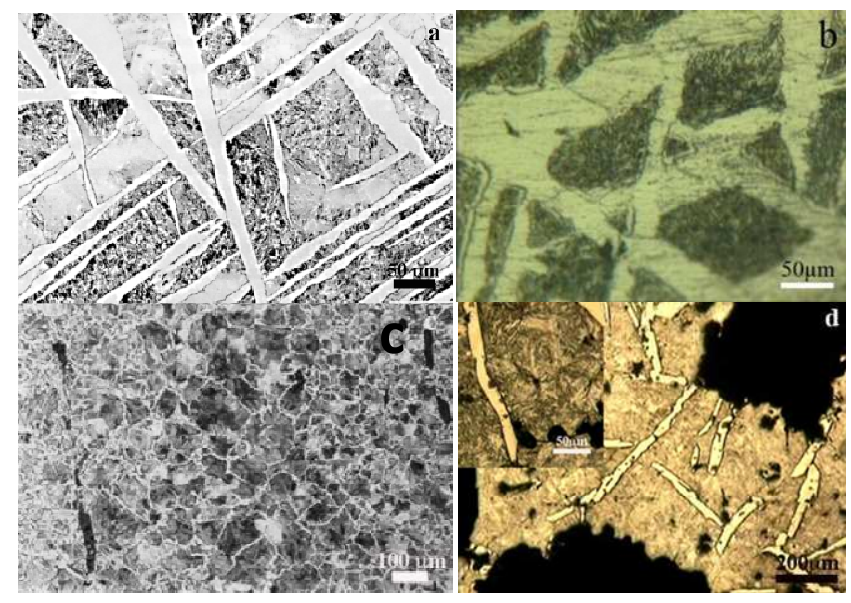

Figure 6. Optical micrographs of as-smelted samples (a) 1988 smelting, (b) recent smelting, (c) as-smelted after forging by a traditional smith, (d) recent smelting sample after annealing at $800^{\circ} \mathrm{C}$ during 1 hour in laboratory. 
Scanning electron microscopy (SEM) images of the more recent sample in Fig. 7 confirm the various microstructures: the Widmannstätten structure (Fig. 7a), the peculiar pearlites as elongated grains shown in Fig. $7 \mathrm{~b}$, the large grains of ferrite with probably a fayalite in the grains boundaries (Fig. 7c).

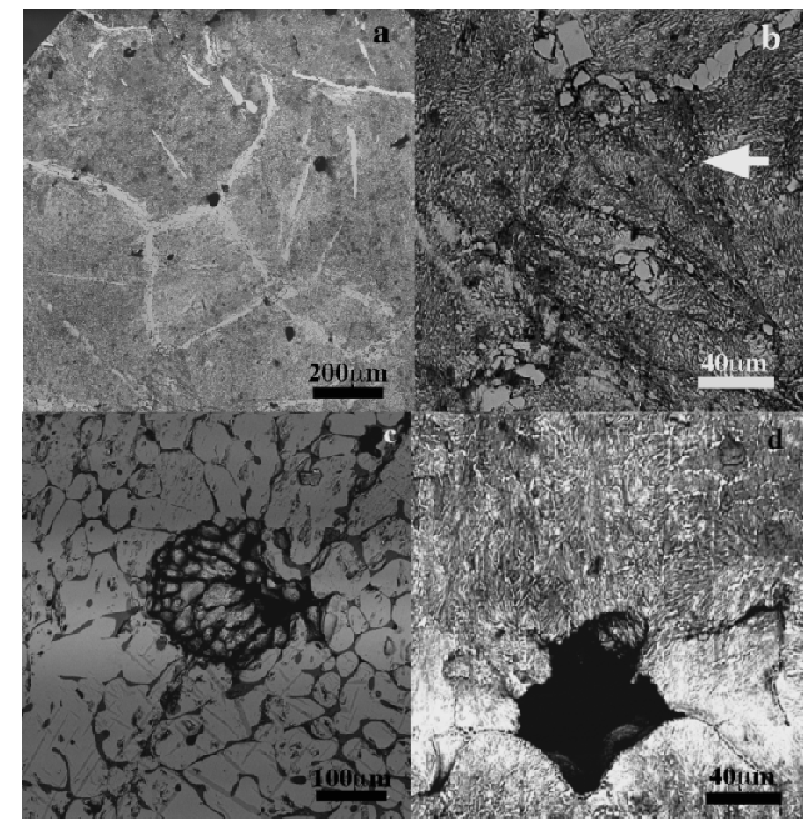

Figure 7. Scanning Electron Microscopy (SEM) images of a recent smelting sample: (a) Widmannstätten structure, (b) Elongated pearlite, (c) Large grains of ferrite with fayalite in grains boundaries, (d) Finer pearlite with hardness indentation.

The refining of the pearlite can be seen in Fig. $7 \mathrm{~d}$ with a hardness indentation. Concerning this mechanical property, previous measurements on the sample of 1988 gave the value of $150-250 \mathrm{Hv}$ following the areas investigated. Recent micro-hardness measurements indicate large values ringing from 100 to $700 \mathrm{Hv}$. It is known that the ferrite hardness ranged from 100 to 150 while that of pearlite from 200 to 700 . Often values of about 400 and 700 were measured indicating the variation of carbon content in the bi-phased microstructures. The carbon content of the as-obtained product is estimated at $2.2 \mathrm{wt}$. \% by ATD analyse.

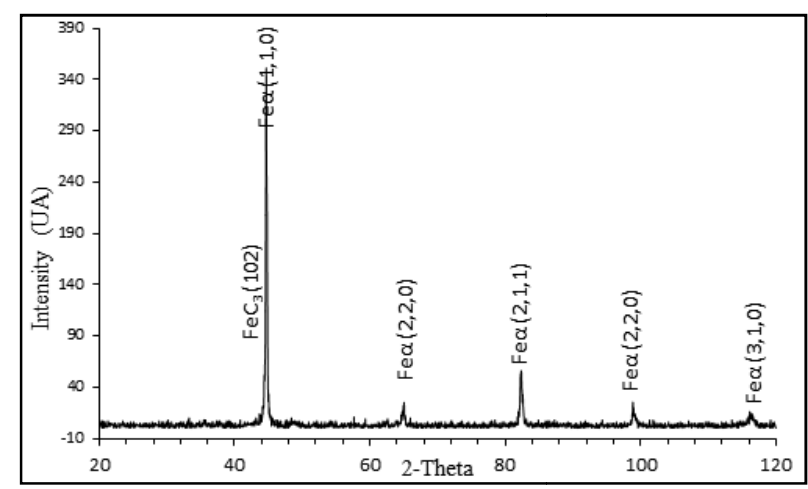

Figure 8. X-rays diffraction (XRD) patterns of recent as-smelted steel sample.
Fig. 8 exhibits the XRD patterns of the as-smelted sample. The X-rays diffraction patterns indicate the presence of cubic centred ferrite (bcc-Fe $\alpha$ ) and tetragonal cementite $\left(\mathrm{t}-\mathrm{Fe}_{3} \mathrm{C}\right)$. In addition, numerous carbon inclusions were observed in the as-smelted sample without knowing whether they were amorphous carbon or graphite.

\section{Discussion}

The 1988 Bandjeli's iron smelting seems to be the latest that can be experimentally described although some recent smelting were likely made with regard to the as-smelted products examined in this paper. In order to keep investigating the as - smelted iron of Bandjeli, this peculiar method must be described with metallurgical orientation in addition to the anthropological, historical and archaeological ones. The former presentation can open physical and chemical metallurgy studies in one part to improve the smelting technique and in second part for in-depth researches on structure-properties relationships of the as smelted iron.

The Bandjeli's furnace described above belongs to the group of natural draught furnace using a peculiar method to product steel in Africa according to Van der Merwe [28]. The description of the furnace construction and its operating mode indicate that the smelters have owned some specializations with skills and practices enabling a reproducibility of the as-smelted iron. Tools were used for the various measurements: wooden sticks for dimensions, basket for volume and weight, flame coloration for temperature and sounds like for pressure and the progression of the iron reduction. The reproducibility of the smelting practices was also confirmed by the microstructural examinations of the various samples from different smelting. The chemical processes usually involved in the reduction of hematite ore at high temperature in case of direct reduction is given in reaction (1); or in reaction (2) in carbon monoxide atmosphere.

$$
\begin{aligned}
2 \mathrm{Fe}_{2} \mathrm{O}_{3}+3 \mathrm{C} & \rightarrow 4 \mathrm{Fe}+3 \mathrm{CO}_{2} \\
\mathrm{Fe}_{2} \mathrm{O}_{3}+3 \mathrm{CO} & \rightarrow 2 \mathrm{Fe}+3 \mathrm{CO}_{2}
\end{aligned}
$$

In the case of the Bandjeli's furnace, the ignition of the charcoal in the centre of the iron ore starts the heating process. This operation likely induces the incomplete combustion of the charcoal that produces enough $\mathrm{CO}$ to initiate the reaction (2). This suggestion is in the agreement with the absence of flame or smoke on the top of the furnace during practically the whole process. In addition, the MS by using the three buffers placed at the beginning into the tuyeres within the door managed to monitor the air input into the furnace. Theses buffers were completely released 23 hours after the ignition of the furnace during the hottest phase of the smelting operation. The two measured temperatures $\mathrm{T}=800^{\circ} \mathrm{C}$ and $\mathrm{T}>1000^{\circ} \mathrm{C}$ in the tuyere while the hottest areas in the furnace are respectively at the level of the belly and at half height between this level 
and that of the tuyeres indicate that the combustion within the furnace is downward.

Otherwise, the amount of charcoal over the ore would be vanished from complete combustion with smoke and flame. The chemical reduction of the ore within the Bandjeli's furnace is likely due to the $\mathrm{CO}$ which amount is probably increased by the effect of the layer of fresh woods. The long constant temperature of $800^{\circ} \mathrm{C}$ during about 20 hours at the level of the tuyeres in the hearth contributes to the reduction of the ore that falls downward with the liquid slag. The latter partially covers the tuyeres during this phase that explains their permanent cleaning by the MS. Its occurrence within the tuyeres is also a control parameter for the MS on the progression of the smelting operation. Allowing the flow of the liquid slag outside the furnace is likely a way to reduce it in the hearth in order to avoid the re-carburisation of the pure iron. It can be assumed that the iron-smelters of Bandjeli produce intentionally a kind of steel.

The Bandjeli's smelting process must be endorsed as reproducible technical method of producing steels like any method of material processing although the operating procedure remained to be investigated in details. The Widmannstätten structure obtained for Bandjeli as-smelted product is typically observed in low carbon steel $(0.2 \% \mathrm{C})$ and high pro-eutectoid steel $(1.2 \% \mathrm{C})$ following the cooling operation [34]. In any case this structure is not involved in for instance cast grey iron. Its typical occurrence in the Bandjeli's steel and most generally in the as-smelted traditional Africa's steels indicate that these materials contain about 2 wt.\% C. The Bandjeli's steel shows microstructure with variable pearlite grains size and cementite content as well as variable sized needles of ferrite highlighting the cooling history of each part of the ingot during the smelting process. The hardness value about $200 \mathrm{Hv}$ is typical for the Widmannstätten structure with variable proportion of ferrite and pearlite. Furthermore, some microstructure features are likely bainitic with fine needles raising the hardness at about $400 \mathrm{Hv}$ and the higher one to about $700 \mathrm{Hv}$. XRD patterns show mainly the presence of ferrite with a cell parameter of about $0.286 \mathrm{~nm}$ in accord with the microstructural observation. The presence of ferrite, Widmannstätten structure and the hardness data indicate that the iron reduction product from Bandjeli's method is steel. We will hereafter name it Bandjeli's steel (BS) [35]. This steel and the smelting operation described here need more metallurgical investigations in order to evaluate its potential contribution to the improvement of the iron casting industry.

\section{Conclusion}

We have described an ancient Iron smelting process of Bandjeli in Togo. Microstructural and mechanical properties of recent as-obtained product were investigated and results are compared to that obtained by Hahn in 1988. SEM and optical micrographs indicate a Widmannstätten structure. Micro-hardness values range from 100 to $700 \mathrm{Hv}$.
XRD analyses show the presence of ferrite with a cell parameter of about $0.286 \mathrm{~nm}$. These results confirm and complete those obtained by Hahn. The presence of ferrite, Widmannstätten structure and hardness data indicate that the iron reduction product from Bandjeli's method is steel with good properties suitable for forging agricultural tools. Bandjeli's method can be considered as peculiar technique because of its reproducibility and the characteristics of the as-smelted steel. Obviously, further studies are needed on this material. However the description of the smelting process accounted in this paper is necessary to evaluate the contribution of this technique to the improvement of the iron industry. Furthermore, this paper will facilitate in-depth metallurgical investigations on the Bandjeli's steel.

\section{Acknowledgements}

Mr. SERTCHI Madjintiba is gratefully acknowledged for giving the samples examined in this paper. This project was supported by the French government through the "Service de Coopération et d'Actions Culturelles" of the French Embassy in Lomé, Togo.

\section{References}

[1] H. P. Hahn, Techniques de métallurgie au Nord Togo (Collection Patrimoines, 6). Lomé: Université de Bénin. (1997), (first published as: "Eisentechniken in Nord-Togo", Münster 1993)

[2] H. P. Hahn, Die materielle Kultur der Konkomba, Kabyè und Lamba in Nord-Togo. Ein regionaler Kulturvergleich. (Westafrikanische Studien, 14). (1996) Köln: Köppe J. Clerk Maxwell, A Treatise on Electricity and Magnetism, 3rd ed., vol. 2. Oxford: Clarendon, 1892, pp.68-73

[3] N. Yamaguchi: A trial to reproduce an ancient iron-making process in Chiba prefecture; ISIJ International, Vol. 37 (1997), No. 2, pp. 97-101

[4] C.V. Bellamy: A West-African smelting house", JISI 56 (1904), p 99-126

[5] C. Goucher : "Technological change in Bassar iron production", Nyame Akuma 23 (1983), p.36

[6] C. Goucher, The iron industry of Bassar, Togo: An interdisciplinary investigation of African technological History, Dissertation for $\mathrm{PhD}$ degree, University of California, Los Angeles (1984)

[7] E. Coulibaly: Savoirs et savoir-faire des anciens métallurgistes d'Afrique Occidentale, KARTHALA, Paris, (2006)

[8] H. Bocum, Introduction générale, in Aux Origines de la Métallurgie du Fer en Afrique: Une ancienneté méconnue Afrique de l'Ouest et Afrique Centrale, H. Bocum (ed), Eds UNESCO, Paris, 2002, pp. 9-17

[9] Tylecote R. F., 1975, "Iron Smelting at Taruga, Nigeria", Journal of The Historical Metallurgy society, IX (1975) $49-56$ 
[10] K. Adekola: The African Diaspora Archaeology Network Newletter march (2011), 1

[11] P. de Barros, "Societal repercussions of the rise of large- scale traditional iron production: a West African example", The African Archaeological Review, 6 (1988), p.91-113

[12] B. Martinelli (1982): "Métallurgistes Bassar", Thèse de doctorat, Etudes et Documents de Sciences Humaines Nr.5, Lomé

[13] R. Haaland (1985): "African Ironworking - ancient and traditional", London

[14] M. S. Bisson, S. T. Childs, P. De Barros, A. F. C. Holl, Ancient African Metallurgy : the socio-cultural context, J. O Vogel (ed.), AltaMira Press, 2000

[15] P. de Barros: "Iron industry of the Bassar", Nyame Akuma 23 (1983), p.32-35

[16] P. de Barros, "Bassar: a quantified, chronologically controlled, regional approach to a traditional iron production centre in West Africa", Journal of the International African Institute 56 (1986), p. 148-173)

[17] R. Cornevin, Les Bassari du nord Togo, Éditions Berger-Levrault, Paris, 1962

[18] S. Dugast: "La pince et le soufflet", Journal des Africanistes, (1986) vol.56 (2), p.29-60

[19] L. Frobenius: Und Afrika sprach, 3 (1913): Unter den unsträflichen Äthiopen. Berlin: Vita

[20] W. Koert: Mitteilungen von Forschungsreisenden und Gelehrten aus den deutschen Schutzgebieten (MFGdS) 19 (1906), 111

[21] U. Kachinsky, Les gisements de fer au Togo, Revue Togo-Cameroun, Octobre 1933

[22] R. MAUNY, "Histoire de métaux en Afrique occidentale", Bulletin de l'IFAN, t. XIV, (1952), p. 578

[23] R. Fisch, Nord-Togo und seine westliche Nachbarschaft. Basel Basler Missionsbuchhandlung (1911). p. 162
[24] Fr. Hupfeld: Die Eisenindustrie in Togo", Deutsche Schutzgebiet 12 (1899), 175-191

[25] Z. J. von Graf: Mitteilungen von Forschungsreisenden und Gelehrten aus den Deutschen Schutzgebieten 9 (1896), 89.

[26] C. Robion- Brunner, B. Martinelli (ed.), Métallurgie du fer et Sociétés africaines, British Archaeological Reports (2012)

[27] SERNEELS V., ROBION-BRUNNER C., Perret S., La sidérurgie en pays dogon : problématiques, premiers résultats et perspectives, Etudes maliennes, no 65 (2007), p. 113-126

[28] N. van der Merwe, Production of high carbon steel in the African Iron Age: the Direct Steel Process, Proc. 8th PanAfrican Cong. of Prehistoric and Quaternary Studies, Leakey, R.E. \& Ogot, B.E. (eds) (1980), 331-334

[29] H. P. Hahn, ZB1. Geol. Paläont. Teil I 3/4 (1995), 445

[30] L. M. Pole: Decline or Survival? Iron production in Westafricain, Journal of African History 23 (1982), 503-513

[31] R. Haaland, "Man' role in the changing habitat of Mema during the old kingdom of Ghana", Norwegian Archaeological Review (1980) 13: 31-46

[32] J. F. Jemkur, Les débuts de la métallurgie du fer en Afrique de l'Ouest, in Aux Origines de la Métallurgie du Fer en Afrique : Une ancienneté méconnue Afrique de l'Ouest et Afrique Centrale, H. Bocum (ed), Eds UNESCO, Paris, 2002, pp. 23-33. (Meroe)

[33] S. Passarge, In Meyer, H. (Hg.) Das deutsche Kolonialreich. Eine Länderkunde der deutschen Schutzgebiete. Leipzig Bibliographisches Institut (1910), pp. 49

[34] A. Schrader, A. Rose, Structure of Steels, de Ferri metallurgica T. II, Verlag Stahleusen M.B.H, Dusseldorf, (1966), pp. 306-307

[35] Pali KPELOU et al., Etude métallurgique du fer brut traditionnel de Bandjeli, Rev. Ivoir. Sci. Technol., 20 (2012) 24-34 